\title{
Faktor yang Berhubungan dengan Kenaikan Berat Badan Bayi Berat Lahir Rendah
}

Daffa Hafizh Afian, ${ }^{1}$ Moh. Syarofil Anam, ${ }^{2}$ Ari Budi Himawan, ${ }^{3}$ Adhie Nur Radityo Suswihardhyono ${ }^{3}$

${ }^{1}$ Program Studi Kedokteran, ${ }^{2}$ Bagian Ilmu Kesehatan Anak, ${ }^{3}$ Bagian Ilmu Kesehatan Masyarakat Fakultas Kedokteran Universitas Diponegoro, Semarang

Latar belakang. Bayi berat lahir rendah (BBLR) memiliki risiko morbiditas, keterlambatan pertumbuhan dan gagal tumbuh. Faktor yang berhubungan kenaikan berat badan BBLR perlu diketahui agar risiko keterlambatan pertumbuhan dapat dikendalikan.

Tujuan. Menganalisis faktor-faktor yang berhubungan dengan kenaikan berat badan BBLR di RSUD R.A. Kartini Jepara.

Metode. Penelitian ini merupakan studi kasus kontrol. Subyek dibagi dalam kelompok kasus (BBLR dengan kenaikan berat badan tidak sesuai grafik Fenton) dan kelompok kontrol (BBLR dengan kenaikan berat badan sesuai grafik Fenton), kemudian secara retrospektif diteliti faktor yang berhubungan dengan kenaikan BB selama 4 minggu pemantauan. Faktor-faktor yang diteliti adalah usia kehamilan, berat lahir, komplikasi, jumlah diit dan pemberian nutrisi parenteral.

Hasil. Data dipilih secara consecutive sampling, didapatkan 148 subyek penelitian yang terdiri dari 72 kasus dan 76 kontrol. Didapatkan $36,1 \%$ laki-laki pada kelompok kasus dan 60,5\% pada kelompok kontrol. Hubungan bermakna ditemukan pada kenaikan berat badan pada BBLR dengan jenis kelamin ( $\mathrm{p}=0,003)$, berat lahir $(\mathrm{p}=0,01)$, usia kehamilan ( $\mathrm{p}=0,035)$, komplikasi $(\mathrm{p}=0,037)$ dan jumlah diit minggu kedua $(\mathrm{p}<0,001)$. Namun, tidak terdapat hubungan bermakna antara kenaikan berat badan pada BBLR dengan pemberian nutrisi parenteral $(\mathrm{p}=0,093)$. Kesimpulan. Usia kehamilan, berat lahir, komplikasi dan jumlah diit berhubungan dengan kenaikan berat badan BBLR. Sarî Pediatri $2021 ; 23(2): 75-81$

Kata kunci: bayi berat lahir rendah, kenaikan berat badan

\section{Factors Associated with Weight Gain in Low Birth Weight Baby}

Daffa Hafizh Afian, ${ }^{1}$ Moh. Syarofil Anam, ${ }^{2}$ Ari Budi Himawan, ${ }^{3}$ Adhie Nur Radityo Suswihardhyono ${ }^{3}$

Background. Low birth weight babies (LBW) have a risk of morbidity, weight gain and failure to thrive. It is important to understand factors associated with LBW to control the risk of stunted growth.

Objective. To determine factors associated with weight gain of LBW at R.A. Kartini Hospital Jepara

Method. This is a case control study. Subjects were divided into case groups (LBW with weight gain not in accordance with Fenton's growth chart) and control groups (LBW with weight gain in accordance with Fenton's growth chart). Sex, gestational age, birth weight, complications, amount of enteral feeding and parenteral nutrition were evaluated retrospectively.

Result. Data was selected with consecutive sampling. There were 148 samples consisting of 72 cases and 76 controls, $36.1 \%$ male in the case group and $60.5 \%$ in the control group. There were significant association between weight gain in LBW babies and sex ( $\mathrm{p}=0,003)$, birth weight $(\mathrm{p}=0,01)$, gestational age $(\mathrm{p}=0,035)$, complications $(\mathrm{p}=0,037)$ and the amounts of the second week enteral feeding $(\mathrm{p}<0,001)$. However, there was no significant correlation between weight gain in LBW infants and parenteral nutrition $(\mathrm{p}=0,093)$.

Conclusion. Gestational age, birth weight, complications and the amount of enteral feeding were factors associated with weight gain in LBW babies. Sari Pediatri 2021;23(2):75-81

Keywords: low birth weight babies, weight gain

Alamat korespondensi: Adhie Nur Radityo Suswihardhyono. Departemen Ilmu Kesehatan Anak Fakultas Kedokteran UNDIP/RSUP Dr. Kariadi, Jl. Dr. Sutomo, Semarang Selatan, Kota Semarang 50244. Email: dokter_adhie7@yahoo.com 
B ayi berat lahir rendah (BBLR) menurut World Health Organization (WHO) adalah bayi dengan berat lahir kurang dari 2500 gram. Secara global, diperkirakan $15-20 \%$ dari semua kelahiran, atau $>20$ juta bayi baru lahir setiap tahun merupakan BBLR, 95,6\% di antaranya berada di negara berkembang. Hal tersebut merupakan salah satu masalah kesehatan yang memerlukan perhatian di berbagai negara, terutama di negara berkembang atau negara dengan sosio-ekonomi rendah seperti di Indonesia. Berdasarkan hasil survei Riskesdas tahun 2018, persentase BBLR di Indonesia mengalami penurunan dari $11,1 \%$ di tahun 2010 menjadi 6,2\%. Kejadian BBLR tertinggi terdapat di Provinsi Sulawesi Tengah $(8,9 \%)$ dan terendah di Jambi $(2,6 \%)$, sedangkan di Jawa Tengah sebesar 6,1\%.

Berdasarkan pengamatan secara epidemiologis, bayi dengan berat lahir kurang dari 2500 gram berisiko 20 kali lebih tinggi mengalami kematian dibandingkan bayi berat lahir normal (BBLN). ${ }^{2}$ Penelitian oleh Suparmi didapatkan hasil bahwa BBLR memiliki risiko 9,89 kali lebih tinggi terjadi kematian neonatal dibandingkan dengan bayi yang lahir dengan berat badan normal. Kematian pada kasus BBLR sering disebabkan karena komplikasi neonatal seperti asfiksia, infeksi, aspirasi pneumonia, perdarahan intra kranial, hipoglikemia, hipotermia, maupun gangguan pemberian minum.

Bayi berat lahir rendah juga memiliki risiko lebih besar untuk mengalami morbiditas serta keterlambatan pertumbuhan dan perkembangan dibandingkan dengan BBLN. Neonatus dengan BBLR sering mengalami gagal tumbuh setelah lahir. Neonatus kurang bulan terjadi kehilangan berat badan yang signifikan pada beberapa hari pertama kehidupan dan baru dapat kembali ke berat lahir di usia dua minggu. Gangguan pertumbuhan BBLR ini dapat berlanjut, dan jika pemberian nutrisi tidak mencukupi, akan menyebabkan bayi mudah mengalami infeksi yang akhirnya anak berisiko menjadi stunting. Anak dengan riwayat kelahiran BBLR berisiko 5,6 kali lebih besar untuk menjadi stunting dibanding anak dengan BBLN.

Bayi berat lahir rendah lebih sering terjadi pada bayi lahir preterm. Hambatan pertumbuhan ekstrauterin (berat badan berdasarkan umur gestasi dibawah persentil 10) dijumpai pada $75 \%$ bayi preterm pada usia 28 hari. Bayi preterm secara umum memiliki risiko untuk terjadi poor feeding, defisiensi nutrisi, dan hambatan pertumbuhan.'
Pentingnya pertumbuhan BBLR secara optimal mendorong penulis untuk meneliti faktor-faktor yang berhubungan dengan kenaikan berat badan BBLR di Rumah Sakit Umum Daerah (RSUD) R.A. Kartini Jepara. Faktor yang diteliti adalah usia kehamilan, berat lahir, komplikasi BBLR, jumlah diit yang didapat dan pemberian nutrisi parenteral selama perawatan.

\section{Metode}

Penelitian ini merupakan penelitian analitik dengan metode rancangan kasus kontrol (case control) retrospektif. Kelompok kasus merupakan BBLR dengan peningkatan berat badan tidak sesuai target, sedangkan kelompok kontrol adalah BBLR dengan peningkatan berat badan sesuai target. Target kenaikan berat badan dinilai berdasarkan grafik Fenton. Adapun faktorfaktor yang akan dinilai secara retrospektif melalui catatan medik adalah usia kehamilan, berat lahir, ada tidaknya komplikasi, jumlah diit dan pemberian nutrisi parenteral.

Sampel penelitian ini adalah BBLR yang dirawat di RSUD R.A. Kartini Jepara pada bulan Januari 2019 sampai dengan Januari 2020. Pemilihan subyek penelitian dilakukan dengan metode consecutive sampling dari catatan medis BBLR di RSUD R.A. Kartini Jepara yang memenuhi kriteria inklusi dan eksklusi. Kriteria inklusi meliputi catatan medik BBLR yang dirawat di RSUD R.A. Kartini Jepara dan memenuhi catatan pemantauan minimal 4 minggu. BBLR dengan kelainan kongenital berat atau yang meninggal dalam perawatan dieksklusi dari penelitian. Analisis data dilakukan dengan analisis deskriptif dan uji chi-square.

\section{Hasil}

Didapatkan 148 responden yang terdiri atas 72 BBLR yang mengalami peningkatan berat badan tidak sesuai target grafik Fenton (kasus) dan 76 BBLR yang mengalami peningkatan berat badan sesuai target grafik Fenton (kontrol). Karakteristik subyek penelitian tertera pada Tabel 1. Proporsi laki-laki $(48,6 \%)$ dan perempuan $(51,4 \%)$ hampir sama. Mayoritas subyek adalah bayi preterm $(75,5 \%)$. Berdasarkan berat lahir, sebagian besar termasuk kategori BBLR $(83,1 \%)$ dibanding BBLSR (16,9\%). Komplikasi BBLR terjadi pada 87,2\% subyek. 
Tabel 2 menunjukkan bahwa terdapat perbedaan yang bermakna antara kelompok kasus dan kontrol pada variabel usia kehamilan, berat lahir, panjang badan (PB) lahir, dan jenis kelamin.

Tabel 3 menunjukkan bahwa kenaikan berat badan BBLR yang diukur dengan grafik Fenton berhubungan dengan jenis kelamin, berat lahir, usia kehamilan, komplikasi, dan jumlah diit yang diberikan pada usia
2 minggu. Namun, kenaikan berat badan BBLR tidak berhubungan dengan pemberian nutrisi parenteral.

Komplikasi yang dinilai pada penelitian ini adalah asfiksia, gangguan napas, sepsis atau infeksi neonatorum dan hiperbilirubinemi. Komplikasi yang paling banyak diderita adalah hiperbilirubinemi (113 subyek). Gangguan nafas merupakan komplikasi yang berhubungan dengan kenaikan berat badan BBLR (Tabel 4).

Tabel 1. Karakteristik subyek penelitian

\begin{tabular}{lcc}
\hline Karakteristik & $\mathrm{n}(\%)$ & Median (Min-Maks) \\
\hline Jenis kelamin & $72(48,6)$ & \\
$\quad$ Laki laki & $76(51,4)$ & \\
$\quad$ Perempuan & & $34,00(27-41)$ \\
Usia kehamilan (minggu) & $36(24,3)$ & \\
$\quad$ Aterm & $112(75,7)$ & \\
$\quad$ Preterm & & $1900,00(1025-2480)$ \\
Berat lahir (gram) & $123(83,1)$ & \\
$\quad$ BBLR & $25(16,9)$ & \\
BBLSR & & \\
Panjang lahir (cm) & & \\
Kenaikan BB dalam 4 minggu (gram) & & \\
Komplikasi & & \\
$\quad$ Tidak ada & $19(12,8)$ & \\
Ada & $129(87,00-400-1300)$ \\
1 Komplikasi & $51(34,5)$ & \\
2 Komplikasi & $46(31,1)$ & \\
3 Komplikasi & $25(16,9)$ & \\
$\quad$ Komplikasi & $7(4,7)$ & \\
\hline
\end{tabular}

Tabel 2. Data karakteristik kelompok kasus dan kontrol

\begin{tabular}{|c|c|c|c|}
\hline Variabel & $\begin{array}{r}\text { Kasus } \\
(\mathrm{n}=72)\end{array}$ & $\begin{array}{c}\text { Kontrol } \\
(\mathrm{n}=76)\end{array}$ & $\mathrm{p}$ \\
\hline Usia kehamilan (minggu) & $33(27-41)^{\Phi}$ & $35(29-39)^{\Phi}$ & $0,000^{\# *^{*}}$ \\
\hline Berat Lahir (gram) & $1800(1025-2450)^{\Phi}$ & $2200(1200-2480)^{\Phi}$ & $0,000^{\# *^{*}}$ \\
\hline PB Lahir (cm) & $41,5(37-49)^{\Phi}$ & $44(38-49)^{\Phi}$ & $0.002^{\# *}$ \\
\hline Jenis Kelamin & & & $0,003^{*^{*}}$ \\
\hline Laki-laki & $26(36,1 \%)$ & $46(60,5 \%)$ & \\
\hline Perempuan & $46(63,9 \%)$ & $30(39,5 \%)$ & \\
\hline
\end{tabular}


Tabel 3. Hasil uji chi-square hubungan tiap variabel terhadap peningkatan berat badan BBLR

\begin{tabular}{|c|c|c|c|}
\hline \multirow[b]{2}{*}{ Variabel } & \multicolumn{2}{|c|}{ Kenaikan berat badan } & \multirow[b]{2}{*}{$\mathrm{p}$} \\
\hline & $\begin{array}{l}\text { Kasus } \\
(\mathrm{n}=72)\end{array}$ & $\begin{array}{c}\text { Kontrol } \\
(\mathrm{n}=76)\end{array}$ & \\
\hline Jenis kelamin (\%) & & & $0,003^{¥ *}$ \\
\hline Laki-laki & $26(36,1)$ & $46(60,5)$ & \\
\hline Perempuan & $46(63,9)$ & $30(39,5)$ & \\
\hline Berat lahir (\%) & & & $0,01^{¥^{*}}$ \\
\hline BBLR & $54(75)$ & $69(90,8)$ & \\
\hline BBLSR & $18(25)$ & $7(9,2 \%)$ & \\
\hline Usia kehamilan (\%) & & & $0,035^{z^{*}}$ \\
\hline Preterm & $60(83,3)$ & $52(68,4)$ & \\
\hline Aterm & $12(16,7)$ & $24(31,6)$ & \\
\hline Komplikasi (\%) & & & $0,037^{z^{*}}$ \\
\hline Ada & $67(93,1)$ & $62(81,6)$ & \\
\hline Tidak ada & $5(6,9)$ & $14(18,4)$ & \\
\hline Pemberian diit (\%) & & & $0,000^{¥ *}$ \\
\hline$<200 \mathrm{cc} / \mathrm{kg} / \mathrm{hr}$ & $40(55,6)$ & $10(13,2)$ & \\
\hline$>200 \mathrm{cc} / \mathrm{kg} / \mathrm{hr}$ & $32(44,4)$ & $66(86,8)$ & \\
\hline Parenteral nutrisi (\%) & & & $0,093^{¥}$ \\
\hline Diberikan & $24(33,3)$ & $16(21,1)$ & \\
\hline Tidak & $48(66,7)$ & $60(78,9)$ & \\
\hline
\end{tabular}

${ }^{\#}$ Mann whitney; ${ }^{*}$ chi-square; ${ }^{*}$ signifikan $(\mathrm{p}<0,05)$

Tabel 4. Hubungan komplikasi dengan kenaikan berat badan BBLR

\begin{tabular}{|c|c|c|c|}
\hline \multirow[b]{2}{*}{ Variabel } & \multicolumn{2}{|c|}{ Kenaikan berat badan } & \multirow[b]{2}{*}{$\mathrm{p}$} \\
\hline & $\begin{array}{c}\text { Kasus } \\
(\mathrm{n}=72)\end{array}$ & $\begin{array}{c}\text { Kontrol } \\
(\mathrm{n}=76)\end{array}$ & \\
\hline Asfiksia (\%) & & & $0,469 ¥$ \\
\hline Tidak asfiksia & $53(73,6)$ & $51(67,1)$ & \\
\hline Ringan & $8(11,1)$ & $12(15,8)$ & \\
\hline Sedang & $8(11,1)$ & $12(15)$ & \\
\hline Berat & $3(4,2)$ & $1(1,3)$ & \\
\hline Gangguan napas (\%) & & & $0,004 ¥^{*}$ \\
\hline Ada & $31(43,1)$ & $16(21,1)$ & \\
\hline Tidak ada & $41(56,9)$ & $60(78,9)$ & \\
\hline Infeksi/sepsis (\%) & & & $0,567 ¥$ \\
\hline Ada & $22(30,6)$ & $20(26,3)$ & \\
\hline Tidak ada & $50(69,4)$ & $56(73,7)$ & \\
\hline Hiperbilirubinemi (\%) & & & $0,241 ¥$ \\
\hline Ada & $58(80,6)$ & $55(72,4)$ & \\
\hline Tidak ada & $14(19,4)$ & $21(27,6)$ & \\
\hline
\end{tabular}




\section{Pembahasan}

Jenis kelamin subyek penelitian ini secara keseluruhan seimbang antara laki laki $(48,6 \%)$ dan perempuan $(51,4 \%)$, tetapi terdapat perbedaan pada proporsi jenis kelamin antara kelompok kontrol dan kasus. Hal ini menggambarkan adanya pengaruh perbedaan jenis kelamin terhadap potensi pertumbuhan sehingga sebagian besar referensi dan standar telah menetapkan kurva pertumbuhan berbeda untuk jenis kelamin laki laki dan perempuan. Menurut kurva pertumbuhan Fenton, janin laki-laki memiliki kenaikan berat badan yang sedikit lebih tinggi $( \pm 5,8 \mathrm{gram} / \mathrm{minggu})$ dan pertumbuhan panjang yang hampir sama dibandingkan dengan wanita selama 24-36 minggu usia kehamilan. Penelitian lebih lanjut diperlukan untuk memperjelas apakah itu merupakan fenomena fisiologis karena perbedaan genetik atau potensi risiko yang lebih tinggi pada anak laki-laki untuk tumbuh lebih cepat dibandingkan anak perempuan pada bayi preterm yang sehat.

Penelitian ini memiliki sampel dengan rata-rata usia kehamilan adalah 34,03 $( \pm 2,93)$ minggu, dengan usia kehamilan termuda 27 minggu dan tertua 41 minggu. Sampel penelitian terdiri atas $112(75,7 \%)$ kehamilan preterm dan $36(24,3 \%)$ aterm. Secara fisiologis, berat badan bayi semakin bertambah sesuai dengan usia kehamilan. Hal tersebut sesuai dengan penelitian yang dilakukan di RSIA Kendangsari Surabaya yang menunjukkan terdapat hubungan bermakna antara usia kehamilan dengan kejadian BBLR. Resiko BBLR meningkat 13,57 kali pada ibu dengan usia kehamilan 28-36 minggu daripada ibu dengan usia kehamilan 3742 minggu. Hal ini menunjukkan kehamilan preterm berisiko lebih tinggi untuk kejadian BBLR.

Berdasarkan ada atau tidaknya komplikasi, didapatkan 129 (87,2\%) dari keseluruhan subyek terdapat komplikasi. Hal ini sesuai dengan banyak penelitian yang mendapatkan BBLR merupakan faktor yang diketahui terkait dengan mortalitas dan morbiditas neonatal. Faktor penyebab terdapat komplikasi pada sebagian besar BBLR adalah bayi preterm dengan ketidakmatangan organ. Komplikasi sepsis neonatus disebabkan oleh interaksi faktor internal (sistem kekebalan yang belum matang) dan faktor eksternal, seperti praktik penularan / penghentian infeksi yang tidak tepat (dianggap sebagian karena kepatuhan mencuci tangan yang buruk di kamar bayi, kepadatan ruangan yang tinggi, frekuensi fogging ruangan, dan pemilihan antibiotik definitif.

Penelitian ini mendapatkan hasil bahwa usia kehamilan berhubungan dengan kenaikan BB sesuai dengan grafik Fenton pada BBLR. Bayi aterm mempunyai kematangan organ yang lebih baik dibanding preterm. Risiko mortalitas dan morbiditas bayi aterm juga lebih kecil dibanding bayi preterm. Bayi preterm tetap mengalami retardasi pertumbuhan hingga beberapa tahun. Saat dipulangkan dari RS, bayi preterm mungkin hanya memiliki cadangan nutrisi tubuh yang rendah, kekurangan mineralisasi tulang, dan akumulasi defisit energi 3780 hingga $5460 \mathrm{kj}$. Pada usia koreksi kehamilan 40 minggu, bayi preterm umumnya lebih kecil dan memiliki kebutuhan nutrisi yang lebih tinggi dari bayi aterm. Bayi preterm mungkin tetap terhambat pertumbuhannya selama beberapa tahun, memiliki tingkat morbiditas dan mortalitas masa kanak-kanak yang lebih tinggi, memiliki tulang yang tidak termineralisasi, mengalami kegagalan untuk berkembang, dan sering mengalami keterlambatan dalam perkembangan saraf. Hal tersebut dapat bertahan hingga usia sekolah.

Hal tersebut sesuai dengan penelitian observasional prospektif di India yang mengamati 111 bayi preterm di perawatan neonatal level III yang mendapatkan hasil sekitar dua pertiga neonatus preterm saat keluar RS dan tiga perempat saat usia kronologis cukup bulan mengalami hambatan pertumbuhan ekstrauterin (Extra uterine growth retardation / EUGR).

Penelitian ini juga mendapatkan hasil berat lahir berhubungan secara statistik dengan kenaikan $\mathrm{BB}$ sesuai grafik Fenton pada BBLR. Salah satu penyebabnya adalah terhambatnya pemberian nutrisi enteral secara dini dan kurangnya pemberian nutrisi parenteral yang memadai yang akan berakibat penurunan berat badan lebih dari normal di awal kehidupan. Hal ini sesuai dengan penelitian di Bogor yang menyatakan berat lahir, panjang lahir, dan perawakan pendek ibu merupakan faktor risiko dominan dari stunting pada penelitian anak usia 0-23 bulan. Pada penelitian tersebut didapatkan bayi dengan berat lahir kurang dari 3000 gram memiliki 1,8 kali lebih tinggi risiko menjadi stunting dibanding bayi yang memiliki berat lahir lebih dari atau sama dengan 3000 gram.

Penelitian ini mendapatkan hasil adanya komplikasi berhubungan dengan kenaikan BB bayi BBLR, dimana BBLR tanpa komplikasi akan dapat tumbuh sesuai grafik dibanding bayi dengan komplikasi. Hal ini sesuai 
dengan penelitian kohort, multisenter yang dilakukan oleh Ehrenkranz dkk ${ }^{16}$ pada 1660 bayi yang lahir di rumah sakit dengan BB 501 gram sampai 1500 gram dan usia gestasi 24 sampai 29 minggu. Bayi yang tidak mengalami morbiditasi berat mempunyai penambahan berat yang lebih cepat. Kecepatan penambahan berat juga berhubungan dengan durasi pemberian nutrisi parenteral yang lebih pendek dan pemberian nutrisi enteral yang lebih dini.

Sebanyak 97\% dari kasus kelahiran di RSCM merupakan kasus kehamilan yang tidak direncanakan, pasien yang datang hampir semuanya memiliki perawatan kehamilan yang buruk sehingga bayi yang lahir akan mengalami berbagai masalah dari nutrisi, respiratorik, pencernaan, dan berbagai masalah lain. Akibat komplikasi ini dan kondisi dasar bayi preterm, klinisi cenderung menunda pemberian susu sehingga terjadi EUGR. Hal serupa didapatkan dari penelitian di Karachi Pakistan, dari 237 BBLR dalam penelitian tersebut, hiperbilirubinemi $(40,1 \%)$, asfiksia $(25,7 \%)$, sindrom gangguan pernapasan $(21,1 \%)$, hipotermia $(19,8 \%)$, hipoglikemia $(19,0 \%)$ dan sepsis $(13,1 \%)$ merupakan masalah utama pada BBLR diikuti oleh malformasi kongenital (6,3\%), necrotizing enterocolitis (NEC) $(5,1 \%)$ dan intraventricular hemorrhage (IVH) $(4,2 \%)$ bayi. Frekuensi masalah pada BBLR meningkat seiring dengan menurunnya usia kehamilan dan berat lahir.

Komplikasi pada penelitian ini yang secara statistik berhubungan bermakna dengan pertumbuhan $\mathrm{BB}$ adalah gangguan napas. Hasil ini sesuai dengan penelitian yang dilakukan di RS Dr. Sardjito Yogyakarta yang mendapatkan hasil bahwa gangguan pernapasan merupakan komplikasi perinatal yang secara signifikan dikaitkan dengan kegagalan pertumbuhan postnatal selama rawat inap. Bayi dengan gangguan pernapasan mengalami kesulitan mengonsumsi cairan, termasuk makanan enteral sebagai sumber energi utamanya. Ini juga meningkatkan laju metabolisme basal, memperburuk defisit energi total pada bayi preterm dan BBLR. ${ }^{12}$

Jumlah diit yang diberikan pada umur 2 minggu dengan batas minimal pemberian $200 \mathrm{cc} / \mathrm{kgBB} / \mathrm{hari}$ atau ASI ad libitum berhubungan dengan kenaikan BB. Analisis kohort multisenter yang dilakukan di Selandia Baru menunjukkan bahwa asupan gizi dalam 4 minggu pertama berhubungan dengan pertumbuhan pada usia 4 minggu dan 36 minggu umur koreksi. Protein berkorelasi lebih kuat dengan pertumbuhan dari pada makronutrien lain dan asupan protein pada minggu ke-2 berkorelasi paling kuat dengan pertumbuhan lingkar kepala. Asupan protein bisa turun secara signifikan pada minggu kedua setelah lahir selama masa transisi dari makanan intravena ke enteral, jika ASI tidak difortifikasi. Sebagai ilustrasi, ASI yang tidak difortifikasi pada 150 $\mathrm{mL} / \mathrm{kgBB} / \mathrm{hari}$ hanya memasok protein $2 \mathrm{~g} / \mathrm{kgBB} / \mathrm{hari}$ berbeda dengan ASI yang difortifikasi bisa memberikan 3,5 hingga 4,1 gram $/ \mathrm{kgBB} /$ hari. Bayi preterm sering mengalami intoleransi minum, yaitu ketidakmampuan untuk mencerna nutrisi enteral yang ditandai dengan peningkatan residu lambung, distensi abdomen dan/ atau muntah. ${ }^{20}$

Sebagian besar kasus intoleransi minum diakibatkan oleh imaturitas saluran cerna pada bayi preterm. Bayi preterm juga terdapat ketidakmatangan fungsi mekanis, seperti koordinasi mengisap-menelan, tonus sfingter gastroesofageal, pengosongan lambung dan motilitas usus. Akibat intoleransi minum pencapaian minum penuh pada bayi preterm dapat terhambat sehingga dapat menyebabkan gangguan gizi. Sementara bayi dengan usia gestasi $>34$ minggu umumnya dapat menyusu langsung dari ibu karena refleks hisap dan menelannya sudah cukup baik.

Penelitian ini mendapatkan hasil bahwa pemberian nutrisi parenteral tidak berhubungan dengan kenaikan BB BBLR. Keterbatasan penelitian retrospektif ini adalah pemberian nutrisi parenteral tidak dibedakan jenis dan jumlah makronutrien yang diberikan tiap $\mathrm{kgBB}$ per hari sehingga asupan nutrisi dari pemberian parenteral tidak bisa dihitung secara rinci. Pemberian nutrisi parenteral harus dapat mencukupi kebutuhan makro dan mikronutrien bayi preterm. Nutrisi parenteral yang diberikan harus mengandung cairan, elektrolit, kalori, protein, lemak, vitamin dan mineral dalam jumlah yang cukup. Beberapa penelitian menunjukkan bahwa pemberian asam amino dan lemak melalui parenteral dapat ditoleransi oleh bayi preterm sejak hari pertama kehidupan. Penelitian efek pemberian nutrisi parenteral secara agresif (protein dimulai $2 \mathrm{~g} / \mathrm{kgBB} /$ hari ditingkatkan hingga $3,5 \mathrm{~g} / \mathrm{kgBB} /$ hari) dibandingkan dengan pemberian standar (protein diberikan $1 \mathrm{~g} / \mathrm{kgBB} /$ hari ditingkatkan bertahap hingga $3 \mathrm{~g} / \mathrm{kgBB} / \mathrm{hari}$ ) disamping pemberian lipid $0,5 \mathrm{~g} / \mathrm{kgBB} /$ hari ditingkatkan secara bertahap, mendapatkan hasil pertambahan berat lebih cepat pada kelompok studi dan menunjukkan luaran yang lebih baik saat ke luar dari perawatan. ${ }^{19}$ 


\section{Kesimpulan}

Usia kehamilan, berat lahir, ada tidaknya komplikasi, dan jumlah diit saat usia kronologis 2 minggu berhubungan dengan kenaikan berat badan BBLR yang diukur dengan grafik Fenton. Namun pemberian nutrisi parenteral selama perawatan pada penelitian ini tidak berhubungan dengan kenaikan berat badan BBLR.

\section{Daftar pustaka}

1. United Nations Children's Fund and World Health Organization. Low Birthweight: Country, regional and global estimates [Internet]. New York; 2004. Diakses pada 27 Feb 2020. Didapat dari: https://www.unicef.org/publications/files/ low_birthweight_from_EY.pdf.

2. Cutland CL, Lackritz EM, Mallett-Moore T, dkk. Low birth weight: Case definition $\&$ guidelines for data collection, analysis, and presentation of maternal immunization safety data. Vaccine 2017;35:6492.

3. Kementerian Kesehatan RI. Laporan Hasil Riset Kesehatan Dasar Indonesia Tahun 2018 [Internet]. Jakarta; 2018. Diakses pada 1 Mar 2020. Didapat dari: https://archive.org/details/Lap oranRiskesdas2018NasionalPromkes.net.

4. Suparmi, Chiera B, Pradono J. Low birth weights and risk of neonatal mortality in Indonesia Health Science. J Indonesia 2016;7:113-7

5. Kosim MS. Gawat darurat neonatus pada persalinan preterm. Sari Pediatri 2006;7:225-31.

6. Lubis NFM, Lubis BM, Tjipta GD, dkk. Nutrisi agresif untuk neonatus kurang bulan. Cermin Dunia Kedokteran 2019;46:377-9.

7. Nasution D, Nurdiati DS, Huriyati E. Berat badan lahir rendah (BBLR) dengan kejadian stunting pada anak usia 6-24 bulan. Jurnal Gizi Klinik Indonesia 2014;11(1).

8. Wandita S. Pemberian minum pada bayi prematur kecil masa kehamilan. Kumpulan makalah lengkap kongres nasional ilmu kesehatan anak XVII Jogjakarta. Jogjakarta: Sinas IDAI 2017.h.514-20.

9. Ikatan Dokter Anak Indonesia. Konsensus Asuhan Nutrisi pada Bayi Prematur [Internet]. Jakarta; 2016. Diakses pada 9 Mar 2020. Didapat dari: http://spesialis1.ika.fk.unair.
ac.id/wp-content/uploads/2018/03/Konsensus-Asuhan-NutrisiPrematur.pdf.

10. Zhang L, Li Y, Liang S, Liu X-J, Kang F-L, Li G-M. Postnatal length and weight growth velocities according to Fenton reference and their associated perinatal factors in healthy late preterm infants during birth to term-corrected age: an observational study. Ital J Pediatr 2019;45: 1-...

11. Purwanto AD, Wahyuni CU. Hubungan antara umur kehamilan, kehamilan ganda, hipertensi dan anemia dengan kejadian bayi berat lahir rendah (BBLR). Jurnal Berkala Epidemiologi. 2016;4:349-59.

12. Leksomono N, Sutomo R, Haksari EL. Predictors of early growth failure in preterm, very low birth weight infants during hospitalization. Paediatrica Indones 2019;59:44-50.

13. Carver JD, Wu PYK, Hall RT, dkk. Growth of preterm infants fed nutrient-enriched or term formula after hospital discharge. Pediatrics 2001;107:683-9.

14. Kumar M, Tripathi S, Agrawal N, Singh SN. Growth of premature neonates admitted in a level III neonatal unit. Clin Epidemiol Global Health 2014;2:56-60.

15. Utami NH, Rachmalina R, Irawati A, Sari K, Rosha BC, Amaliah N. Short birth length, low birth weight and maternal short stature are dominant risks of stunting among children aged 0-23 months: evidence from Bogor Longitudinal Study on Child Growth and Development, Indonesia. Mal J Nutr 2018;24:11-23.

16. Ehrenkranz RA, Younes N, Lemons JA, dkk. Longitudinal growth of hospitalized very low birth weight infants. Pediatrics 1999;104:280-9.

17. Rohsiswatmo R, Amandito R. Optimalisasi pertumbuhan bayi prematur dan pasca prematur di Indonesia; mengacu pada pedoman nutrisi bayi prematur di Rumah Sakit Cipto Mangunkusumo. Sari Pediatri 2019;21:262-70.

18. Shaikh F, Laghari GS, Syal AR, Hameed A, Nizamani MA. Complications of low birth weight babies during first 72 hours of life. Med Channel 2016;22:18-24.

19. Cormack BE, Jiang Y, Harding JE, Crowther CA, Bloomfield FH. Relationships between neonatal nutrition and growth to 36 weeks' corrected age in ELBW babies-secondary cohort analysis from the provide trial Nutrients 2020;12:760.

20. Rundjan L, Tirtaningrum Y, Anindita C. Penanganan paripurna bayi pematur di ruang perawatan. Jakarta: Pelayanan kesehatan anak terpadu. Pendidikan Kedokteran berkelanjutan LXV. Departemen Ilmu Kesehatan Anak Fakultas Kedokteran Universitas Indonesia RS Cipto Mangunkusumo. 2013:18-49. 